\title{
The Ionizing Radiation-Induced Bystander Effect: Evidence, Mechanism, and Significance
}

\author{
Edouard I. Azzam, Sonia M. de Toledo, Andrew L. Harris, \\ Vladimir Ivanov, Hongning Zhou, Sally A. Amundson, \\ Howard B. Lieberman, and Tom K. Hei
}

\begin{abstract}
It has long been considered that the important biological effects of ionizing radiation are a direct consequence of unrepaired or misrepaired DNA damage occurring in the irradiated cells. It was presumed that no effect would occur in cells in the population that receive no direct radiation exposure. However, in vitro evidence generated over the past two decades has indicated that non-targeted cells in irradiated cell cultures also experience significant biochemical and phenotypic changes that are often similar to those observed in the targeted cells. Further, nontargeted tissues in partial body-irradiated rodents also experienced stressful effects, including oxidative and oncogenic effects. This phenomenon, termed the "bystander response," has been postulated to impact both the estimation of health risks of exposure to low doses/low fluences of ionizing radiation and the induction of second primary cancers following radiotherapy. Several mechanisms involving secreted soluble factors, oxidative metabolism, gap-junction intercellular communication, and DNA repair, have been proposed to regulate radiation-induced bystander effects. The latter mechanisms are major mediators of the system responses to ionizing radiation exposure, and our knowledge of the biochemical and molecular events involved in these processes is reviewed in this chapter.
\end{abstract}

E.I. Azzam $(\bowtie) \bullet$ S.M. de Toledo

Department of Radiology, New Jersey Medical School Cancer Center,

University of Medicine and Dentistry of New Jersey, Newark, NJ 07103, USA

e-mail: azzamei@umdnj.edu; detolesm@umdnj.edu

\author{
A.L. Harris \\ Department of Pharmacology and Physiology, New Jersey Medical School, \\ University of Medicine and Dentistry of New Jersey, Newark, NJ 07103, USA \\ e-mail: aharris@umdnj.edu \\ V. Ivanov $\bullet$ H. Zhou $\bullet$ S.A. Amundson $\bullet$ H.B. Lieberman $\bullet$ T.K. Hei \\ Center for Radiological Research, Department of Radiation Oncology, \\ College of Physicians and Surgeons, Columbia University Medical Center, \\ New York, NY, USA \\ e-mail: vni3@columbia.edu; hz63@ columbia.edu; HBL1@ @olumbia.edu; tkh1@columbia.edu
}

S.T. Sonis and D.M. Keefe (eds.), Pathobiology of Cancer Regimen-Related Toxicities, 


\section{Introduction}

The absorption of ionizing radiation by living cells can directly disrupt atomic structures, producing chemical and biological changes. It can also act indirectly through radiolysis of water, thereby generating reactive chemical species that may damage nucleic acids, proteins, and lipids [1] (Fig. 1). Together, the direct and indirect effects of radiation initiate a series of biochemical and molecular signaling events that may repair the damage, or culminate in permanent physiological changes or cell death [2].

Interestingly, the early biochemical modifications, which occur during or shortly after radiation exposure, were thought to be responsible for most of the effects of ionizing radiation in mammalian cells. However, oxidative changes may continue to arise for days and months after the initial exposure, presumably because of inflammatory responses $[3,4]$ and continuous generation of reactive oxygen (ROS) and nitrogen (RNS) species [5]. Remarkably, these processes occur not only in the irradiated cells but also in their progeny [2, 6-9]. Furthermore, radiation-induced oxidative stress may spread from targeted cells to non-targeted bystander cells

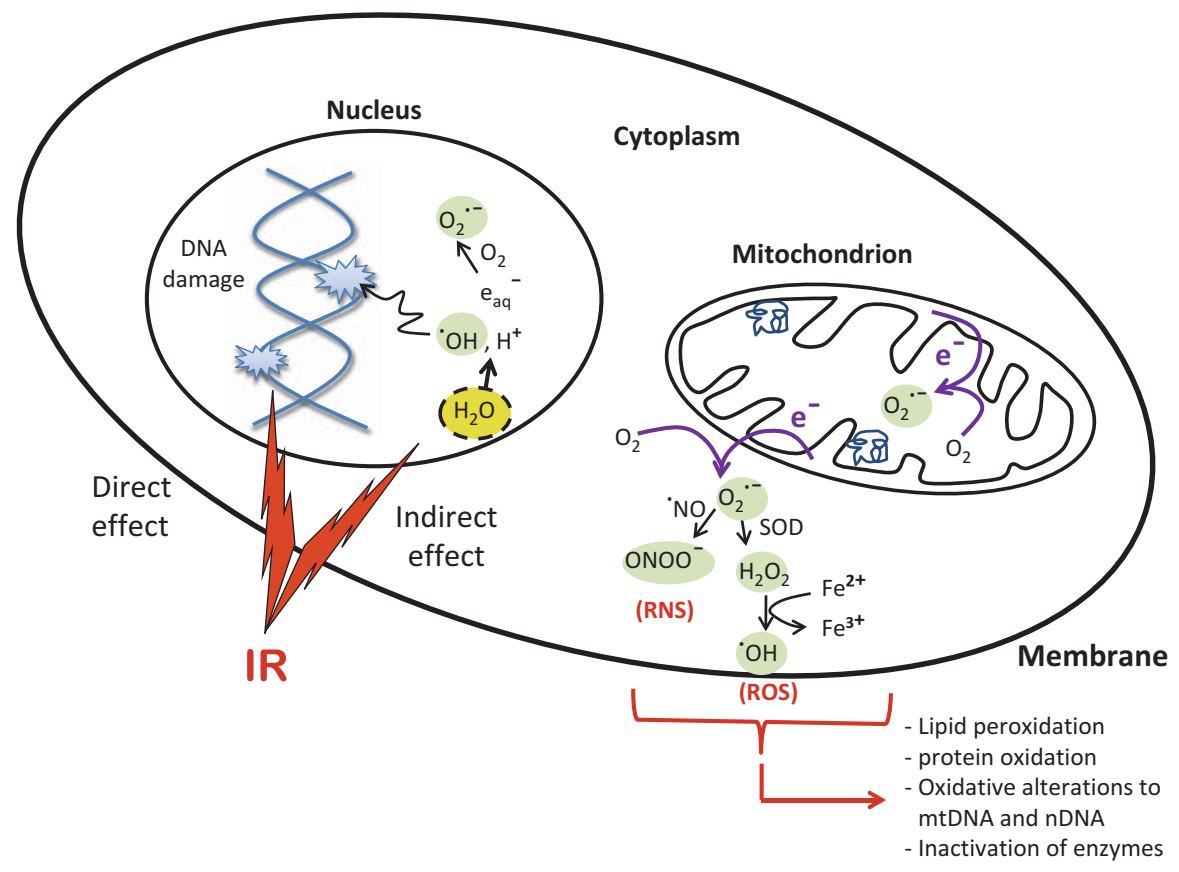

Fig. 1 The direct and indirect effects of ionizing radiation on cellular macromolecules. Absorption of ionizing radiation by living cells directly disrupts atomic structures, producing chemical and biological changes and indirectly through radiolysis of cellular water and generation of reactive chemical species by stimulation of oxidases and nitric oxide synthases. Ionizing radiation may also disrupt oxidative metabolism and other mitochondrial functions contributing to persistent alterations in lipids, proteins, nuclear DNA (nDNA), and mitochondrial DNA (mtDNA) 


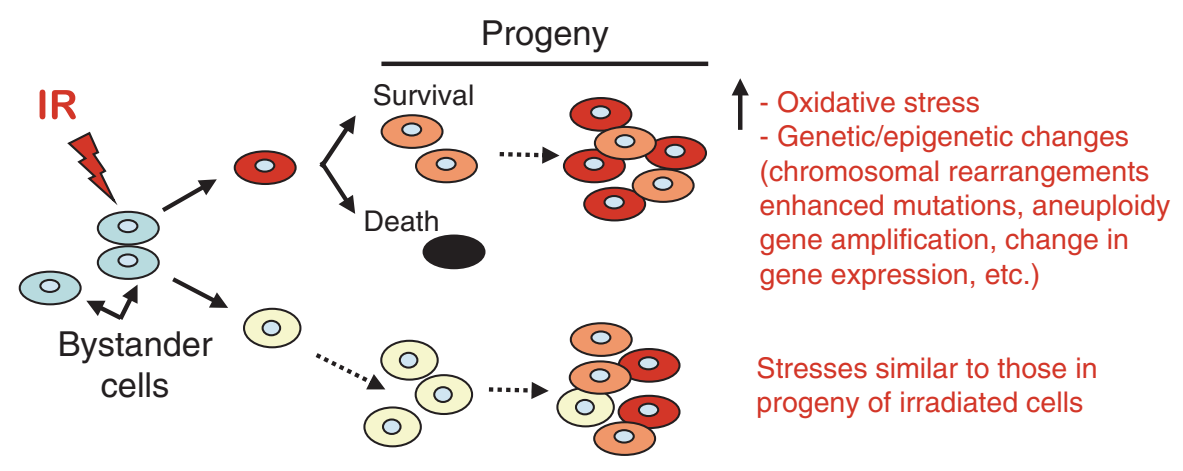

Fig. 2 Ionizing radiation (IR) induces targeted and non-targeted (bystander) effects. Communication of stress-inducing molecules from cells exposed to IR propagates stressful effects, including oxidative stress, as well as genetic and epigenetic changes, to the bystander cells and their progeny. The induced effects may be similar in nature to those observed in progeny of irradiated cells

through intercellular communication mechanisms (reviewed in [10-13]). The progeny of these bystander cells also experience perturbations in oxidative metabolism and exhibit a wide range of oxidative damages, including protein carbonylation, lipid peroxidation, and enhanced rates of spontaneous gene mutations as well as neoplastic transformation [14-16] (Fig. 2). The persistence of such stressful effects in progeny cells may have profound implications for long-term health risks, including the emergence of a second malignancy following radiotherapy treatments [17-20]. Understanding the mechanisms underlying non-targeted effects, together with those that mediate targeted effects, will be informative for counteracting adverse health effects caused by exposure to ionizing radiation, and may lead to formulation of countermeasures.

\section{Ionizing Radiation Track Structure and the Nature of Induced Biological Effects}

Strong evidence has shown that the magnitude and nature of radiation-induced bystander effects greatly depend on the biophysical properties of the impacting radiation. Thus, a review of bystander effects would be facilitated by a brief introduction to the different types of ionizing radiation and their energy deposition patterns.

Ionizing radiation is classified as either electromagnetic or particulate. Whereas $\mathrm{X}$ and $\gamma$ rays belong to electromagnetic radiation, energetic electrons, protons, neutrons, $\alpha$-particles, and heavy charged particles are different forms of particulate radiation [1]. Many of the damaging effects of radiation are due to the geometry of the physical energy deposition of the impacting radiation, referred to as 
Fig. 3 Complexity of DNA damage. The complexity of DNA damage induced by ionizing radiation is highly dependent on the biophysical characteristics of the radiation, in particular its linear energy transfer (LET) properties ionizing radiation-induced

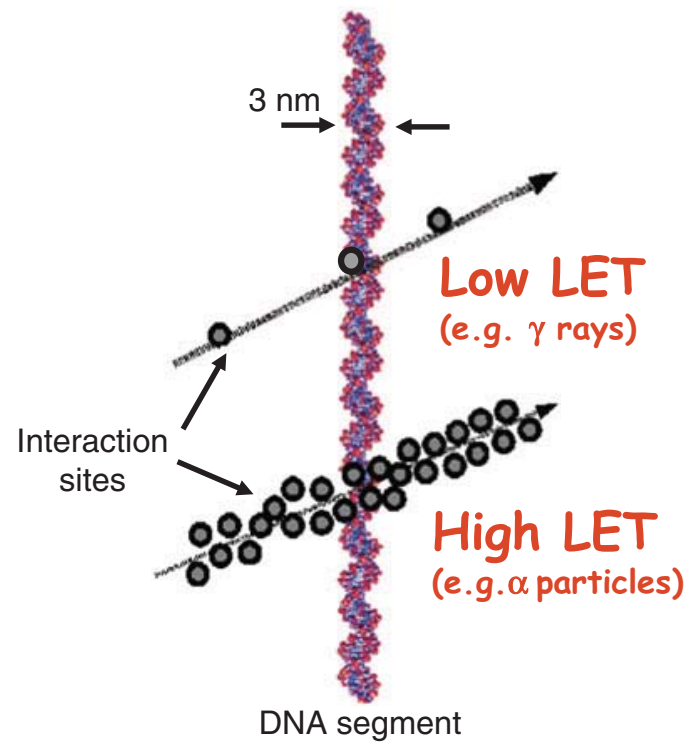

the track structure or linear energy transfer (LET) effects [21]. In irradiated cells, such energy deposition causes endogenous bursts of ROS that result mainly from water radiolysis in and around the radiation track as well as in the intercellular matrix. The differences in ionization patterns due to different types of radiation mainly arise from differences in charge-to-mass ratio of the impacting particles; for example, $\alpha$-particles differ from electrons by a factor of $\sim 8,000$. Thus, whereas low-LET $X$ and $\gamma$ rays produce sparse ionization and excitation events along their trajectory, high LET $\alpha$-particles or high charge $(Z)$ and high energy $(E)$ HZE particles produce a dense track of ionizations and excitations along the particle path [22]. The track structure determines the relative potency of different types of radiation in causing biological effects [23, 24] (Fig. 3). Following exposure to high LET radiations (e.g., $\alpha$-particles, HZE particles), the yield of locally multiply damaged sites (LMDS) in DNA is greatly increased [6, 25, 26].

Whereas $\sim 60$ ROS per nanogram of tissue are generated within less than a microsecond from a hit caused by ${ }^{137} \mathrm{Cs} \gamma$ rays, $\sim 2,000$ ROS are generated from a $3.2 \mathrm{MeV}$ $\alpha$-particle traversal, which corresponds to an ROS concentration of $\sim 19 \mathrm{nM}$ in the nucleus [27]. Such a nuclear ROS concentration can obviously cause extensive oxidative injury and modify normal biochemical reactions [28, 29]. As a result, different signaling cascades responding to these stress conditions are triggered. For example, adaptive responses encompassing DNA repair and antioxidation reactions may be triggered following exposures to low doses of low LET radiations ( $\mathrm{X}$ and $\gamma$ rays) [30-32]. The protective mechanisms may overcompensate, resulting in stimulatory responses that enhance the well-being of the organism long after the exposure [33, 34]. In contrast, basal and induced signaling cascades do not seem to completely alleviate the complex damages induced by low fluences of high LET radiations (e.g., 
$\alpha$ - and HZE particles) [35-37] or high doses of $X$ and $\gamma$ rays [38]. Damaging effects endure and may spread to neighboring bystander cells [39] and persist in their progeny $[15,16]$ (Fig. 2). Thus, the track structure is crucial for dictating the size and precise location of the initial radiation-induced ROS bursts and their subsequent signaling or damaging effects [40-43]. The bursts of ROS, and also of RNS resulting from activation of nitric oxide synthases may affect directly or indirectly proteins/ genes that participate in oxidative metabolism $[44,45]$. The persistence of such perturbations in the normal oxidative metabolism is associated with chronic inflammatory responses [6, 46, 47], which impacts non-targeted effects (reviewed in $[48,49]$ ).

\section{Ionizing Radiation-Induced Bystander Responses}

In a landmark study in 1992, Nagasawa and Little [39] presented evidence indicating that genetic changes occurred in a greater number of cells than expected when Chinese hamster ovary cell cultures were exposed to low fluences of $\alpha$-particles that targeted only a small fraction of the cells. An enhanced frequency of sister chromatid exchanges (SCEs) in 20-40\% of Chinese hamster ovary cells was observed in cultures exposed to fluences by which only $0.1-1 \%$ of the cells' nuclei were actually traversed by a particle track. These results indicated that the target for genetic damage by $\alpha$-particles is much larger than the nucleus or in fact much larger than the cell itself. Those observations in $\alpha$-particle-irradiated cell cultures were soon confirmed by other laboratories [50-55]. Similar effects were also detected in cocultures of bystander cells and cells exposed to external beams of low LET radiations [56-60] and high LET radiations besides $\alpha$-particles [61, 62], thus highlighting their relevance to radiotherapy, diagnostic radiology, and health risks of environmental and occupational exposures (reviewed in [11-13, 63]). In related studies, it has also been shown that when cells are labeled with tritiated thymidine in a three-dimensional multicellular cluster model, a cytotoxic effect is transmitted to adjoining non-labeled cells present in the same cluster [56, 60].

Consistent with these studies, a cytotoxic bystander effect produced by tumor cells labeled with 5-[25]iodo-2'-deoxyuridine was demonstrated in vitro [64] and in vivo [59]. Furthermore, media transfer experiments have shown that incubating nonirradiated cells with growth medium harvested from $\alpha$-particle or $\gamma$-irradiated cell cultures can induce biological effects in the medium-recipient cells [65-67]. Together, the studies have shown that upregulation of stress-responsive genes and proteins, genetic and epigenetic changes, induction of cell cycle checkpoints and cell killing occur in both irradiated and neighboring bystander cells, and the effects occur in various cell types of human and rodent origin at different stages of growth (reviewed in [7, 11, 12, 63, 68-73]). Mechanistic studies have shown that direct and indirect modes of intercellular communication, oxidative metabolism, and DNA repair processes can mediate these effects $[53,74,75]$; however, the exact molecular steps involved have not been defined [76]. 
In addition to observations in tissue culture experiments, significant radiation-induced bystander effects were detected in human tissue models [77-79] and in animal experiments [7, 80-82]. Significantly, $\alpha$-particle emitters concentrated in the liver of Chinese hamsters showed that all cells in the liver are at the same risk for the induction of chromosome damage, when only a small fraction of the total liver cell population is exposed to $\alpha$-particles $[83,84]$. With significance to cancer risk, non-targeted oncogenic radiation effects were observed in the cerebellum of radiosensitive mice, when only the rest of their body was X-irradiated [85]. Besides radiotherapy, where often only small areas of the body are irradiated, the occurrence of in vivo stressful non-targeted effects could have significant consequences during particular activities, such as mining or space travel, when often only parts of the human body are irradiated at any one time [17]. In the case of deep space travel, it has been estimated that an astronaut's body would be exposed, daily, to very low mean doses of densely ionizing radiations [86]. At the typical doses encountered [87, 88], only a very small fraction of cells in the human body would experience the large ionization events created along the tracks of such radiations $[87,88]$. Moreover, the radiation traversals would be separated in both tissue location and time [61]. The possibility of increased risk of carcinogenesis caused by exposure to space radiation during prolonged space travel has been considered a limiting factor for human space exploration [89].

Whereas radiation-induced bystander effects have been extensively investigated in the past 20 years, interactions between irradiated and nonirradiated cells have been suggested from observations made decades earlier showing that blood plasma from individuals undergoing radiotherapy or from individuals who were accidentally irradiated has a clastogenic effect on normal nonexposed cells [90, 91].

Overall, a multitude of studies challenge the paradigm that radiation traversal through the nucleus of a cell is the only prerequisite for the production of genetic damage or a biological response. They indicate that cells in the vicinity of directly irradiated cells or those receiving media from irradiated cultures can respond to the radiation exposure. They denote that cell populations exposed to ionizing radiation respond as an integrated unit rather than separate individual cells that have been irradiated. They point to a critical role for intercellular communication in mediating bystander responses.

Bystander effects are not unique in demonstrating that biological changes can occur in cells that do not receive radiation directly. Evidence gathered over the last two decades from two different areas of study has also shown that genetic damage in cells need not be a direct consequence of direct nuclear irradiation. (1) Genomic instability experiments have shown that the progeny of cells that survive a radiation exposure harbor a spectrum of genetic lesions that are different in nature from the lesions that initially occurred in the irradiated parental cells [35, 38, 92, 93]. The endpoints studied have included malignant transformation [94, 95], chromosomal aberrations [35, 96], specific gene mutations [97], and cell survival [98-100]. Typically, this phenomenon has been studied by examining the occurrence of genetic effects in clonal populations derived from single cells surviving radiation exposure; though, chromosomal instability was also reported in the descendants of unirradiated surviving cells after $\alpha$-particle-irradiation [101]. (2) Individual charged particles 
targeted to specific organelles in the cell using microbeam technology showed that gene mutations do occur following cytoplasmic irradiation [102]. Mutagenesis by cytoplasmic irradiation was induced even by a single $\alpha$-particle traversal and reached a plateau after hits by four to eight particles, which elicited minimal cytotoxicity and induced a class of mutations that is entirely different from those produced by

nuclear irradiation. The nature of the induced mutations consisted mainly of base damage and suggested the involvement of ROS.

\section{Mechanisms of Radiation-Induced Bystander Effects}

The role of transmissible factor(s) generated by irradiated cells: Support of a role for soluble transmissible factor(s) released by irradiated cells that in turn induces effects in nonirradiated cells came not only from medium transfer experiments but also from irradiation of subconfluent cultures with $\alpha$-particles. Targeting the nuclei of a few cells in a subconfluent culture of mammalian cells with $\alpha$-particles resulted in the induction of damage (micronucleus formation and apoptosis) in a greater fraction of cells than those that were irradiated [103]. In these studies, targeting the $\alpha$-particles outside the cells failed to generate an effect, suggesting that the induced bystander effects were due to transmissible factor(s) released from the irradiated cells. Other studies showed that $\alpha$-particle irradiation of cultured cells generated a factor(s) able to induce SCEs in bystander cells; the factor(s) survived freeze thawing and was heat labile [104]. In parallel experiments contrasting those where $\alpha$-particles were targeted outside cells, the same group showed that $\alpha$-particle irradiation of culture medium devoid of cells also caused the generation of SCEinducing factor(s); such factors however were short-lived [104]. In both situations, the supernatant from irradiated cells or irradiated medium caused the induction of excessive SCEs in unirradiated cells to the same extent observed with direct $\alpha$-particleirradiated cell cultures. Interestingly, both the short-lived medium- and cell-derived SCE-inducing activities were inhibited by the antioxidant enzyme superoxide dismutase (SOD), suggesting that ROS are involved in the response.

The effects of $\alpha$-particle-irradiated medium with or without cells on bystander responses were studied by a novel approach utilizing cells plated on either one or both sides of double-mylar dishes [105]. The distance between the mylar surfaces in such dishes was $9.5 \mathrm{~mm}$. It was argued that since low energy $\alpha$-particles can only travel a distance of about $50 \mu \mathrm{m}$ when one side with or without cells was irradiated, cells on the other side would not receive any hits. Irradiation of Chinese hamsterhuman hybrid cells on one side of the dish with 1,10 , or 100 Gy resulted in cytotoxicity to the bystander cells when they were cocultured with the irradiated cells for $48 \mathrm{~h}$. Using the same irradiation setup, Hu et al. [106] demonstrated that protein kinase $\mathrm{C}$ (PKC) epsilon is up-regulated in bystander fibroblasts. Blocking its expression with a small molecule inhibitor reduced the induction of micronuclei in bystanders by either $\gamma$ rays or $\alpha$-particles, supporting a role for PKC signaling in the bystander response. 
It has been suggested that secreted TGF- $\beta 1$ [107-110], IL-8 [111], or prostaglandins $[112,113]$ in the medium of $\alpha$-particle-irradiated cultures may have a role in mediating bystander responses. As the signaling molecule(s) have proven difficult to isolate from the culture medium; however, an increasing number of studies have applied focused or whole-genome expression profiling techniques to help gain insight into potential signaling from the irradiated cells and the response in the bystander cells. Medium transfer experiments have been used to investigate bystander gene expression triggered by low LET $\gamma$ - or X-ray exposures in both fibroblasts [114] and lymphoblasts [115, 116] or erythroleukemia cells [117]. Genes involved in oxidative phosphorylation and mitochondrial function and dysfunction were overrepresented among the genes responding in bystanders in experiments with fibroblasts [114] and lymphoblasts [118]. Interestingly, in the lymphoblasts, some mitochondrial genes responded the same in irradiated cells and bystanders, but a subset of these genes were up-regulated by direct irradiation and down-regulated in the bystanders. A similar result was reported in erythroleukemia cells, where $0.6 \%$ of the genes were found to change in the opposite direction in bystanders and irradiated cells [117].

Gene expression has also been profiled in fibroblast bystanders to high LET particle-irradiated cells, using medium transfer [118], carbon ion microbeam irradiation [119], and a two-layered Mylar strip dish [55]. The latter case employs custom culture dishes, consisting of two concentric rings with a thin Mylar bottom on the outer dish, and strips of thicker Mylar on the inner dish, allow $\alpha$-particle bystander exposures in situ. The cells are grown as a contiguous monolayer, but only the cells growing directly on the thinner Mylar will be exposed to $\alpha$-particles, while the adjacent bystanders growing on the thicker Mylar strips will be completely shielded. Using this approach, we have documented an attenuated response of genes regulated by TP53 in the bystander cells, and a robust response of NFKBregulated genes [55]. The NFKB response was essentially identical in both magnitude and timing in the irradiated cells and bystanders. Further network analysis also implicated KDM5B and HDAC1 and 2 in gene regulation in bystander fibroblasts. These regulators were found to change at the protein level in both irradiated and bystander cells, suggesting a possible role for epigenetic regulation of bystander responses [56].

Network analysis also implicated AKT in early signal transduction, possibly through the GSK3B/CTNNB1 pathway. We found that AKT was phosphorylated in response to radiation by half an hour after exposure, when there was no change in bystanders. By 1-4 h after exposure, however, levels were similarly elevated in both the irradiated and bystander cells [120]. CTNNB1 was also dephosphorylated to similar levels between 4 and $8 \mathrm{~h}$ after exposure in both irradiated and bystander cells.

The same series of experiments also identified a number of genes coding for potential extracellular signaling molecules that were up-regulated in both irradiated and bystander fibroblasts. These included genes previously implicated in bystander response, such as IL8, IL1A, and IL1B, as well as new candidates, such as IL6, 
IL33, LIF, and FGF2. We found that blocking the activity of IL33 by adding specific antibodies to the culture medium blocked activation of NFKB in both irradiated and bystander cells [113]. Regulation of IL33 expression in response to direct or bystander irradiation was also confirmed to be under the control of the AKT pathway.

In other experiments involving high LET radiations, a mitogenic bystander effect was also observed. Exposure of normal human lung fibroblasts (NHLF), maintained in culture, to a low mean dose of $\alpha$-particles stimulated their proliferation; the response also occurred when unirradiated cells were treated with supernatants from $\alpha$-particle or heavy ion-irradiated cells. TGF- $\beta 1$ was implicated in mediating the observed effects in the $\alpha$-particle experiments [121], and nitric oxide apparently contributed to the modest enhancement in cell proliferation and induction of micronuclei observed in bystander cells in the heavy ion study [122]. The occurrence of such mitogenic effects has been suggested to contribute to the hyperplastic responses in the conducting airways of the lower respiratory track that occur after inhalation exposure to radon and other environmental stresses [121]. The stimulatory growth response observed in these media transfer studies is contradictory to the observation that transient and permanent arrests in $\mathrm{G}_{1}$ phase of the cell cycle are induced in normal human cell cultures exposed to mean doses as low as $1 \mathrm{cGy}$ where bystander cells participate in the overall response of the exposed cell population [123]. It is possible that following an initial arrest in $\mathrm{G}_{1}$, an enhancement in cell growth of the irradiated cells occurs. Further analyses of the kinetics of induction of molecules associated with cell growth or cell cycle arrest are needed in support of these studies.

In contrast to the above studies, conditioned medium harvested from keratinocytes exposed to $\gamma$ rays (a low LET radiation) and added to recipient control keratinocytes or fibroblasts [65] resulted in a toxic effect in the recipient cells. The effect was dependent on the type and number of cells in the exposed cultures. Medium harvested from irradiated keratinocytes had a greater cytotoxic effect on fibroblast bystander cells than on keratinocytes, while medium from irradiated fibroblasts had no effect on either keratinocyte or fibroblast bystander cells [65]. The factor(s) leading to such bystander effects appeared to be released by the irradiated cells within the first few hours after exposure. It was suggested that the released factor(s) may be a protein as it was labile when heated but stable when frozen [65]. Suggesting a possible link between the bystander response and genomic instability effects, it was shown that medium harvested over several generations from cells surviving $\gamma$-irradiation is cytotoxic to nonirradiated bystander cells [124, 125]. Consistent with induction of apoptosis in the unirradiated cells, a rapid calcium flux, a subsequent loss of mitochondrial membrane potential and increases in ROS were observed in those cells [124].

Participation of gap-junction intercellular communication (GJIC): Evidence for the involvement of GJIC in propagation of bystander effects has been derived from studies with high and low LET radiations [53, 56, 75, 85, 126-131]. Gap junctions 
were shown to mediate the propagation of stressful effects not only between targeted and non-targeted cells (reviewed in [10, 70]), but also among the targeted cells [27, 132]. The intercellular channels that comprise gap junctions are formed by connexin proteins [133]. Manipulation $(\downarrow \uparrow)$ of connexin expression/gap-junction gating by chemical agents, forced connexin expression by transfection, and connexin gene knockout studies provide substantial evidence for the participation of gap junctions in radiation-induced bystander effects [10, 73, 134]. This is supported by stabilization and up-regulation of connexin mRNA and protein by ionizing radiation [135]. Disruption of cholesterol rich areas of the plasma membrane, where gap-junction channels partition [136], attenuated propagation of radiation-induced effects to bystander cells [137].

The participation of gap junctions in stress-induced bystander effects is not unique to ionizing radiation; it was also described in high density cells exposed to chemotherapeutic agents. Toxicity of these compounds was enhanced by the presence of functional gap junctions between the target cells [138-141]. These effects bear a striking functional similarity to the ability of ganciclovir triphosphate generated by herpes simplex virus (HSV) thymidine kinase to pass through gap junctions and kill cells uninfected with HSV and therefore insensitive to ganciclovir [142-146]. Thus, many systems show that gap junctions enhance and spread the effects of toxic agents on target cells. It appears that a compound or "stress signal" that leads to toxic/clastogenic effects can pass through at least some types of gap-junction channels. This can result in stressful effects, including killing of cells adjacent to those exposed to the toxic treatment or a synergistic enhancement of toxicity between exposed cells (for example, as in the case of cells exposed to hyperthermic treatment [147]).

Gap junctions are dynamic structures that are critical for diverse physiological functions [145, 148-152]. By allowing direct intercellular transfer of cytoplasmic molecules, they provide a powerful pathway for direct molecular signaling between cells. Each of the $\sim 20$ forms of connexin [153] forms channels with distinct permeability properties. Though the properties of connexin channels differ, their pores are thought to allow permeation by molecules up to $\sim 1,000 \mathrm{Da}$, well above the size of most second messengers [133]. Our ongoing studies focus on the effects of specific connexins in radiation-induced non-targeted effects. Connexin channels are highly selective among molecular permeants. The selectivity among cytoplasmic permeants is not simply on the basis of size or charge. Although connexin channels are permeable to second messengers [133], different connexins form channels with different selectivities for second messengers [154-156]. For example, ATP, ADP, AMP, glutamate, and glutathione are significantly more permeable through junctional $\mathrm{Cx} 43$ than $\mathrm{Cx} 32$ channels. On the other hand, adenosine and IP3 are more permeable through $\mathrm{Cx} 32$ than through $\mathrm{Cx} 43$ channels. Depending on their composition, connexin channels can discriminate between highly similar second messengers (e.g., cAMP and cGMP, and among inositol trisphosphates [157-161]). By understanding the effects of specific connexins in the nature of radiation-induced responses, countermeasures to the harmful effects of radiation may be formulated and strategies to enhance radiotherapy may be developed. 
Gap junctions and tumor cells: Loss of GJIC is widely regarded to correlate with tumorigenic phenotypes, but there are exceptions. More importantly, it is now clear that connexins play distinct roles in specific stages of cancer progression. Specifically, increased levels of connexin expression and of GJIC are correlated with invasiveness, extravasation, and metastasis in a variety of cancer cells. It has also been noted that primary tumors that are initially GJIC impaired become GJIC competent at the metastatic stage $[162,163]$. For tumor cells with reduced GJIC, development of drugs and methods that can recover or increase GJIC provide a new and potent way to enhance treatment. Several compounds, notably 4-phenylbutyrate, an inhibitor of histone deacetylases, have been shown to increase GJIC of otherwise GJIC-impaired tumor cells, which enhances toxic bystander effects as well as tends to restore growth control [164-166]. Thus, enhancement of GJIC by chemotherapeutic agents in tumor cells, coupled with radiotherapy and the associated transmission of toxic compounds between cells in the irradiated tumor, would offer a therapeutic gain. In contrast, transmission of toxic effects from irradiated to neighboring normal bystander cells would cause a health risk.

Oxidative metabolism mediates signaling events leading to radiation-induced bystander responses: Normal oxidative metabolism is a key endogenous generator of ROS and RNS [167], and homeostatic control of normal cellular growth pathways is tightly dependent on oxidants [168]. A disruption of the balance between oxidant production and antioxidant defense alters the homeostatic cellular redox environment, resulting in a state of oxidative stress that promotes many pathological conditions including degenerative diseases and cancer [169]. The endogenous targets of oxidants are diverse and include nucleic acids, proteins, and lipids.

An indication that ROS are involved in the induction of SCEs in bystander cells present in cell cultures exposed to very low fluences of $\alpha$-particles was suggested when the bystander effect was inhibited by SOD, a superoxide radical scavenger [107]. Subsequent studies using more direct approaches have shown that low doses of $\alpha$-particles initiate the intracellular production of ROS (superoxide anions and hydrogen peroxide) in human cells through involvement of the plasma bound NADPH-oxidase [104]. These studies suggested that the ROS response did not require direct nuclear or even cellular hits by $\alpha$-particles [104]. In other studies, the antioxidant DMSO reduced the lethal effects imparted on bystander cells by ${ }^{3} \mathrm{H}-\mathrm{TdR}$-labeled cells present in the same 3D cell cluster [170]. Interestingly, maximum protection of the bystander cells was observed in the presence of both DMSO and lindane, an inhibitor of GJIC [170].

Oxidative metabolism has also been implicated in toxic bystander effects observed in media transfer experiments involving $\gamma$-radiation [171-173]. Treatment of the irradiated cultures with the antioxidants L-lactate and L-deprenyl [171-173] or with drugs that inhibit collapse of mitochondrial membrane potential prevented the cytotoxic effects from irradiated cell-conditioned medium [172]. In vivo experiments have also shown that inflammatory-type responses occur after exposure to ionizing radiation [80]. In those experiments, activation of macrophages and neutrophil infiltration were not direct effects of irradiation, but were a consequence of the 
recognition and clearance of radiation-induced apoptotic cells. The occurrence of such response has been suggested to provide a likely mechanism for the interactions between irradiated and nonirradiated hemopoietic cells both in vitro and in vivo [80]. Such interaction was also observed in out of field in vivo experiments examining the genetic effects of partial organ irradiation. Antioxidants and nitric oxide synthase inhibitors attenuated these effects [174], strongly supporting the role of ROS and RNS in mediating bystander effects $[175,176]$.

ROS scavengers inhibited the induction of mutations following cytoplasmic irradiation [102]. Further, induction of hypoxanthine guanine phosphoribosyltransferase (HPRT) mutations in $\mathrm{CHO}$ bystander cells from cultures exposed to low fluences of $\alpha$-particles was consistent with the involvement of oxidative metabolism in the effect. Whereas the mutations induced in cells directly irradiated through the nucleus with $\alpha$-particles were primarily partial and total gene deletions, over $90 \%$ of those arising in bystander cells were point mutations [177]. Interestingly, point mutations were mainly generated following cytoplasmic irradiations [102].

Further evidence that oxidative metabolism is up-regulated in bystander cells was generated from gene expression studies in human diploid fibroblast cultures exposed to very low fluences of $\alpha$-particles [74]. Whereas p21 $1^{\text {Waf1 }}$ expression examined in situ in cell cultures exposed to low mean doses of $\alpha$-particles occurred in clusters of adjacent cells that far exceed the fraction of cells that were irradiated, active and not boiled SOD inhibited the effect [74]. Enzyme activity analyses indicated that the exogenously added SOD enzymatic activity becomes significantly associated with the cells. Whether this association is limited to the plasma membrane or is internalized by the cells remains to be tested.

Radiation-induced ROS are known to cause damage to various cellular components (reviewed in $[5,178]$ ) and produce double-strand breaks in addition to base damage and single-strand breaks (reviewed in [179-181]). Alpha-particle-induced metabolic ROS production was also shown to activate signaling pathways mediated by p53, MAPK, and PI3K-AKT-GSK3beta in bystander cells [74, 120]. Active SOD and catalase enzymes were capable of suppressing these effects and also inhibited the activation in bystander cells of redox-sensitive transcription factors (e.g., NFאB, AP-1, and ATF2) [74]. Similar to GJIC inhibitors, antioxidant enzymes significantly reduced the excess formation of micronuclei in bystander cells [74]. Of interest is the finding that ROS-activated kinase(s) (e.g., member(s) of the MAPK superfamily) have a role in activation of gap-junction proteins [182]. Binding sites for the redox-sensitive AP-1 and NFKB transcription factors, which are activated by low fluences of $\alpha$-particles, exist in the connexin 43 gene promoter region [183].

In addition to membrane bound oxidases [74, 107], involvement of cell membranes in bystander responses was highlighted by the complete suppression of SCEs and HPRT mutation induction in CHO cells exposed to low fluences of $\alpha$-particles in the presence of Filipin, a drug that disrupts lipid rafts [137]. It is of interest to note that gap junctions have been reported to partition in lipid rafts [136]. Further, critical molecules that participate in inflammatory responses, such as prostaglandinendoperoxide synthase 2 (PTGS2), also known as cyclooxygenase-2 (COX-2), also localize in cholesterol-rich domains of plasma membrane [184]. Using a signal 
transduction pathway-specific SuperArray, we compared differentially expressed genes among nonirradiated control NHLF and bystander cells that were in coculture with $\alpha$-particle-irradiated NHLF [112]. Among the 96 genes represented on the platform, one gene, COX-2, was found to be consistently up-regulated by more than threefold, while the RNA level of insulin growth factor binding protein-3 (IGFBP3) was found to be consistently lower by more than sevenfold in multiple analyses of independent bystander samples. The expression of the COX-2 protein in the nonirradiated bystander cells was further confirmed by western blotting. Addition of the COX-2 inhibitor NS-398 (50 $\mu \mathrm{M})$ suppressed COX-2 activity in NHLF cells and finally, after $24 \mathrm{~h}$, reduced the COX-2 protein level in bystander cells to a nondetectable level [112]. These results indicated that expression of COX-2 is associated with the bystander effect. Subsequent experiments showed that a non-cytotoxic and non-mutagenic dose of NS-398 inhibited the propagation of signaling events leading to bystander mutagenesis at the HPRT locus in NHLF cell cultures exposed to $\alpha$-particles. Therefore, it is attractive to speculate that several mechanisms act in concert to promote the bystander effect.

Involvement of Rad9 in signaling radiation-induced bystander responses: The Rad9 protein was shown to participate in the bystander response to radiation exposure since mouse embryonic stem (ES) cells null for the corresponding gene demonstrate enhanced bystander micronuclei formation and apoptosis relative to wild-type Rad 9 controls [185]. These results suggest that Rad9 might normally suppress the bystander signal, and when the protein is not functioning properly a stronger and perhaps longer lasting persistent signal is produced postirradiation. Rad9 is a multifunctional protein with a variety of activities that promote repair of DNA damage, including roles in several DNA repair pathways and cell cycle checkpoints [186]. If DNA damage induced by radiation is the initiating event for a bystander response, then it is reasonable to speculate that in the absence of $\operatorname{Rad} 9$, damage is not properly repaired and thus an enhanced bystander response will be in effect. Consistent with this model is the previous finding that Chinese hamster ovary cells bearing an xrs-5 mutation, which reduces the ability to repair DNA double-strand breaks, are sensitized relative to wild-type cells to the formation of chromosome aberrations caused by bystander effects induced by a low fluence of $\alpha$-particles [187]. However, since Rad9 has many functions in addition to DNA repair and cell cycle checkpoint control, such as the ability to transactivate transcription of specific downstream target genes and regulate apoptosis, the contribution of these other activities to the bystander response is unknown and thus should also be determined.

\section{Conclusions}

In vitro and in vivo observations have provided strong evidence indicating that molecular events leading to various biological effects, including genetic damage, can be transmitted from irradiated to nonirradiated cells. The phenomenon occurs in 


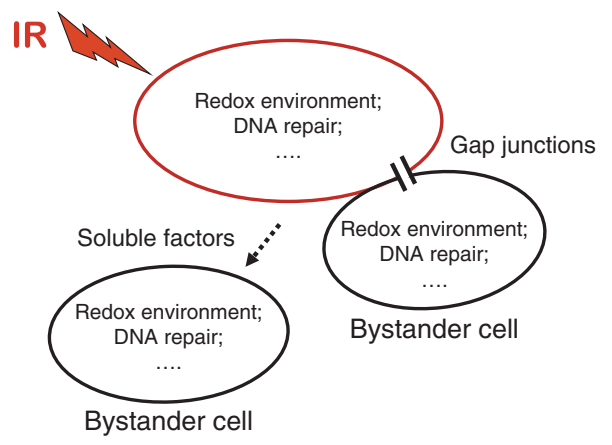

Fig. 4 Mechanisms underlying ionizing radiation-induced bystander effects. Signaling molecules are propagated among irradiated and bystander cells through direct intercellular communication via gap junctions or through diffusible secretion in the surrounding environment. The expression of propagation of bystander effects is highly dependent upon the phenotype of both the irradiated and bystander cells

a variety of cell types of human and rodent origin and involves GJIC, oxidative metabolism, secreted diffusible factors, and DNA repair (Fig. 4). Preliminary evidence points to a crucial role of membrane originating effects where gap junctions and critical enzymes such as COX-2 are located. Further, the expression of connexin proteins has been reported to be modulated by the cellular redox environment and by redox-sensitive soluble factors released by cells exposed to ionizing radiation (e.g., TNF- $\alpha$, IL-1 $\beta$ ) $[188,189]$. However, it is also possible that specific bystander effects are regulated by some mechanism(s) and not by others [105]; this may depend on cell type, cellular growth state, type of radiation, and the biological endpoint being measured.

While direct approaches were used to investigate the role of GJIC in the radiation-induced bystander effect, this remains to be adopted in studies involving oxidative metabolism. In particular, genomic approaches, by which antioxidant enzymes or ROS generating enzymes are overexpressed or underexpressed in cells, coupled with coculture experiments will help identify whether cellular redox environment contributes to the bystander effect at the level of the irradiated and/or the bystander cells.

Current evidence indicates that genetic damage occurs in bystander cells; however, very few studies have examined the reparability of such damage. The fact that cells pre-exposed to an adapting $\gamma$-ray dose are less susceptible to genetic damage induced by bystander mechanisms following exposure to low fluences of $\alpha$-particles [190], and the indication that greater bystander damage occurs in repair-deficient cells [191] is in support of the concept that under certain conditions, bystander damage is amenable to repair or is preventable. Studies with rad9 wild type and mutant cells support this concept.

The radiation-induced lesion(s) that signal expression of the bystander response is under intense investigation [192, 193]: DNA strand breaks, oxidative damage, 
and other targets have been proposed. Studies that focus on identifying such lesion(s) should enhance our understanding of the mechanisms underlying the bystander effect.

\section{Significance}

Radiation protection and radiotherapy are two areas where radiation-induced bystander effects could have significant ramifications.

Radiation protection: The occurrence of a bystander effect in cell populations exposed to low fluences of high LET radiation such as $\alpha$-particles could have a significant impact on the estimation of risks after such exposure [194, 195]. It suggests that cell populations or tissues respond as a whole to radiation exposure and the response is not restricted to that of the individual traversed cells but involves the non-traversed cells also. This would imply that the modeling of dose response relationships at low mean doses, based on the number of cells hit or even on the type of DNA damage they receive, may not be a valid approach. These studies are directly relevant to public health issues where humans are exposed to low fluences of high LET particles. For example, it has been estimated that $10-14 \%$ of lung cancer cases are linked to radon gas in the environment and its $\alpha$-particle-emitting decay products [196]. These estimates were derived by extrapolation from data for high dose exposures to low doses assuming a linear, no threshold dose response. At exposures similar to those from indoor radon, most cells in the bronchial epithelium would not be traversed by an irradiating particle at all and most of the irradiated cells would be traversed by a single particle only [197]. A cell traversed by one $\alpha$-particle receives a substantial dose of radiation $(\sim 0.1-0.5 \mathrm{~Gy})$ and thus would be prone to the deleterious effects of radiation. The studies reviewed here indicate that non-traversed bystander cells exhibit similar genetic alterations, including DNA damage, and hence could contribute to the risk from such exposure. Thus, bystander effect studies, along with other approaches (e.g., epidemiological and toxicological) should contribute to the establishment of not only adequate environmental radiation protection guidelines but also occupational radiation protection standards. An increasing number of workers are currently deployed to decommission and clean nuclear installations, isolate nuclear material, or man space stations. These workers can be accidentally exposed to ionizing radiation including low fluences of $\alpha$-particles and high energy heavy ions.

Radiotherapeutic gain: The induction of cytotoxic effects in bystander cells adjoining irradiated cells has the potential to enhance radiotherapy and help achieve tumor eradication. Evidence for the existence of radiation-induced bystander effects in vivo and elucidation of underlying mechanisms will not only help optimize the contribution of bystander effects to radiotherapy but also provide an explanation to various reports of cytotoxic effects observed in solid tumors located at distant sites from those targeted by radiation. Such abscopal effects, reported as early as 1952 
(reviewed in [69]), led to the regression of a variety of tumors (e.g., [198, 199]). Studies have suggested that ionizing radiation induces the release of cytokines into the circulation which in turn mediate a systemic antitumor effect [199]. Such an effect may involve enhancement of immune activity [200]. Interestingly, in vivo mouse experiments have shown that the Trp53 protein is a key mediator of the radiation-induced abscopal effect [201]. p53 was previously shown to have a role in the secretion of stress-induced growth inhibitors [202]. The secretion of factors capable of inhibitory abscopal/bystander effects when p53 wild-type tumors are irradiated would potentiate the effect of radiation in eradicating tumors.

Bystander effects are thought to have a role in fractionated radiotherapy [203]. Growth medium harvested from cultured cells receiving fractionated irradiation resulted in greater cytotoxic effects when added to bystander nonirradiated cells than growth medium harvested from cultures receiving a single dose of irradiation. This cell killing effect of conditioned medium from irradiated cultures is contrasted with the significant split dose recovery observed in cultures directly exposed to fractionated irradiation [203]. It was argued that if bystander factors were produced in vivo, they may reduce the sparing effect observed in dose fractionation regimens. However, the existence of such factors is likely to be patient, tissue, and life-style specific [204].

A direct role for GJIC has been implicated in antitumor suicide gene therapy protocols by which apoptotic and/or toxic metabolites are transferred through gapjunction channels from affected to bystander cells [205]. Our emerging studies support the role of GJIC in enhancing cell killing when all cells in the population are irradiated [27, 132]. A limitation to enhancing radiotherapeutic gain by such cohort effects is due to the fact that functional GJIC is generally compromised in tumor cells. Specific chemical treatments have been proposed to increase the GJIC capacity of tumor cells and cAMP, retinoic acids, carotenoids, glucocorticoids, and flavenoids have been shown to have such an effect (reviewed in [205]). Up-regulation of gap-junction communication in tumor cells could contribute to the propagation of cell death signals (e.g., calcium ions [206]) generated by cells in tumors that uptake $\alpha$-particle emitters. These radionuclides are being investigated in the treatment of cancer [207-209].

Emergence of second primary cancers following radiotherapy: Since genomic instability is considered a predisposition factor for carcinogenesis, it has been postulated that radiation-induced non-targeted/bystander effects may promote secondary cancer induction in radiotherapy patients [210]. From animal studies with $\mathrm{X}$-rays, there is evidence that irradiation of part of the lung in mice can induce a non-targeted response in the nonirradiated part of the lung through the induction of inflammatory cytokines [211]. Furthermore, our recent evidence (unpublished) and that of others [212] indicates that irradiation of the lower abdomen of mice with $\mathrm{X}$-rays results in the induction of inflammatory response as well as mutations and COX-2 induction [213] in out of field lung tissues. Using the radiosensitive Patched- $1^{+} /^{-}\left(\right.$Ptch $\left.1^{+/}\right)$mouse model system that has a defect in radiation-induced activation of the ATR-Chk1 checkpoint signaling pathway, Mancuso et al. reported induction of medulloblastoma in the nonirradiated brain tissues after partial irradiation 
of the lower half of the animal with a 3 Gy dose of X-rays [85]. Further, based on human serum analyses, there is clear evidence that plasma clastogenic factors are present many years after radiation exposure from the Japanese atomic bomb survivors, Chernobyl liquidators, and from radiotherapy patients [91, 214, 215]. Recently, the frequency distribution of second primary tumor sites in relation to previous irradiation volumes was estimated in a cohort of 115 pediatric patients who developed such cancers [216]. It was estimated that $22 \%$ of secondarily derived tumors arise from a distance of at least $5 \mathrm{~cm}$ from the irradiated site and $\sim 6 \%$ arise from a distance that is $>10 \mathrm{~cm}$ away. A peak second primary tumor frequency of $\sim 31 \%$ was identified in volumes receiving less than $2.5 \mathrm{~Gy}$ and a total of $10-15 \%$ of these tumors are estimated to arise in tissues receiving less than $0.5 \mathrm{~Gy}$. Although these findings are suggestive, nonetheless, the data highlight the potential of second tumor development outside the treatment field and at much lower dose level.

In summary, bystander effect studies have led to a paradigm shift in our understanding of the target theory. They are enhancing our general understanding of intercellular communication under stress conditions. The outcome may contribute to both radiation protection and radiotherapy.

Acknowledgment Grant CA049062 from the National Institutes of Health supported research in the authors' laboratories.

\section{References}

1. Hall EJ, Giaccia AJ. Radiobiology for the radiologist. 6th ed. Philadelphia, PA: Lippincott Williams \& Wilkins; 2006.

2. Spitz DR, Azzam EI, Li JJ, Gius D. Metabolic oxidation/reduction reactions and cellular responses to ionizing radiation: a unifying concept in stress response biology. Cancer Metastasis Rev. 2004;23:311-22.

3. Hayashi T, Kusunoki Y, Hakoda M, Morishita Y, Kubo Y, Maki M, et al. Radiation dosedependent increases in inflammatory response markers in A-bomb survivors. Int J Radiat Biol. 2003;79:129-36.

4. Neriishi K, Nakashima E, Delongchamp RR. Persistent subclinical inflammation among A-bomb survivors. Int J Radiat Biol. 2001;77:475-82.

5. Petkau A. Role of superoxide dismutase in modification of radiation injury. Br J Cancer Suppl. 1987;8:87-95.

6. Kryston TB, Georgiev AB, Pissis P, Georgakilas AG. Role of oxidative stress and DNA damage in human carcinogenesis. Mutat Res. 2011;711:193-201.

7. Tamminga J, Kovalchuk O. Role of DNA damage and epigenetic DNA methylation changes in radiation-induced genomic instability and bystander effects in germline in vivo. Curr Mol Pharmacol. 2011;4:115-25.

8. Limoli CL, Giedzinski E, Morgan WF, Swarts SG, Jones GD, Hyun W. Persistent oxidative stress in chromosomally unstable cells. Cancer Res. 2003;63:3107-11.

9. Limoli CL, Hartmann A, Shephard L, Yang C, Boothman DA, Bartholomew J, et al. Apoptosis, reproductive failure, and oxidative stress in Chinese hamster ovary cells with compromised genomic integrity. Cancer Res. 1998;58:3712-8.

10. Azzam EI, de Toledo SM, Little JB. Oxidative metabolism, gap junctions and the ionizing radiation-induced bystander effect. Oncogene. 2003;22:7050-7. 
11. Hei TK, Zhou H, Chai Y, Ponnaiya B, Ivanov VN. Radiation induced non-targeted response: mechanism and potential clinical implications. Curr Mol Pharmacol. 2011;4:96-105.

12. Mothersill C, Seymour CB. Radiation-induced bystander effects-implications for cancer. Nat Rev Cancer. 2004;4:158-64.

13. Prise KM, O'Sullivan JM. Radiation-induced bystander signalling in cancer therapy. Nat Rev Cancer. 2009;9:351-60.

14. Buonanno M, de Toledo SM, Azzam EI. Increased frequency of spontaneous neoplastic transformation in progeny of bystander cells from cultures exposed to densely-ionizing radiation. PloS One. 2011;6:art. no. e21540.

15. Buonanno M, De Toledo SM, Pain D, Azzam EI. Long-term consequences of radiationinduced bystander effects depend on radiation quality and dose and correlate with oxidative stress. Radiat Res. 2011;175:405-15.

16. Ponnaiya B, Suzuki M, Tsuruoka C, Uchihori Y, Wei Y, Hei TK. Detection of chromosomal instability in bystander cells after Si490-ion irradiation. Radiat Res. 2011;176:280-90.

17. Cucinotta FA, Chappell LJ. Non-targeted effects and the dose response for heavy ion tumor induction. Mutat Res. 2010;687:49-53.

18. Hall EJ, Henry S. Kaplan Distinguished Scientist Award 2003. The crooked shall be made straight; dose-response relationships for carcinogenesis. Int J Radiat Biol. 2004;80:327-37.

19. Tubiana M. Can we reduce the incidence of second primary malignancies occurring after radiotherapy? A critical review. Radiother Oncol. 2009;91:4-15; discussion 1-3.

20. National Research Council. Health risks from exposure to low levels of ionizing radiation. Washington, DC: National Research Council of the National Academies; 2005.

21. Roth RA, Sharma SC, Katz R. Systematic evaluation of cellular radiosensitivity parameters. Phys Med Biol. 1976;21:491-503.

22. Goodhead DT. Spatial and temporal distribution of energy. Health Phys. 1988;55:231-40.

23. Ottolenghi A, Merzagora M, Paretzke HG. DNA complex lesions induced by protons and alpha-particles: track structure characteristics determining linear energy transfer and particle type dependence. Radiat Environ Biophys. 1997;36:97-103.

24. Goodhead DT. Energy deposition stochastics and track structure: what about the target? Radiat Prot Dosimetry. 2006;122:3-15.

25. Ward JF. Biochemistry of DNA lesions. Radiat Res Suppl. 1985;8:S103-11.

26. Georgakilas AG. From chemistry of DNA damage to repair and biological significance. Comprehending the future. Mutat Res. 2011;711:1-2.

27. Autsavapromporn N, de Toledo SM, Little JB, Jay-Gerin J-P, Harris AL, Azzam EI. The role of gap junction communication and oxidative stress in the propagation of toxic effects among high-dose $\alpha$-particle-irradiated human cells. Radiat Res. 2011;175:347-57.

28. Sutherland BM, Bennett PV, Sidorkina O, Laval J. Clustered DNA damages induced in isolated DNA and in human cells by low doses of ionizing radiation. Proc Natl Acad Sci USA. 2000;97:103-8.

29. Nikjoo H, Goodhead DT, Charlton DE, Paretzke HG. Energy deposition in small cylindrical targets by monoenergetic electrons. Int J Radiat Biol. 1991;60:739-56.

30. de Toledo SM, Asaad N, Venkatachalam P, Li L, Howell RW, Spitz DR, et al. Adaptive responses to low-dose/low-dose-rate $\gamma$ rays in normal human fibroblasts: the role of growth architecture and oxidative metabolism. Radiat Res. 2006;166:849-57.

31. Feinendegen LE, Pollycove M, Neumann RD. Whole-body responses to low-level radiation exposure: new concepts in mammalian radiobiology. Exp Hematol. 2007;35:37-46.

32. Wolff $\mathrm{S}$. The adaptive response in radiobiology: evolving insights and implications. Environ Health Perspect. 1998;106 Suppl 1:277-83.

33. Nomura T, Li XH, Ogata H, Sakai K, Kondo T, Takano Y, et al. Suppressive effects of continuous low-dose-rate gamma irradiation on diabetic nephropathy in Type II diabetes mellitus model mice. Radiat Res. 2011;176:356-65.

34. Azzam EI. Exposure to low level environmental agents: the induction of hormesis. Mutat Res. 2011;726:89-90. 
35. Kadhim MA, Macdonald DA, Goodhead DT, Lorimore SA, Marsden SJ, Wright EG. Transmission of chromosomal instability after plutonium $\alpha$-particle irradiation [see comments]. Nature. 1992;355:738-40.

36. Kronenberg A, Gauny S, Criddle K, Vannais D, Ueno A, Kraemer S, et al. Heavy ion mutagenesis: linear energy transfer effects and genetic linkage. Radiat Environ Biophys. 1995;34:73-8.

37. Kronenberg A, Little JB. Molecular characterization of thymidine kinase mutants of human cells induced by densely ionizing radiation. Mutat Res. 1989;211:215-24.

38. Grosovsky AJ, Parks KK, Giver CR, Nelson SL. Clonal analysis of delayed karyotypic abnormalities and gene mutations in radiation-induced genetic instability. Mol Cell Biol. 1996;16:6252-62.

39. Nagasawa H, Little JB. Induction of sister chromatid exchanges by extremely low doses of $\alpha$-particles. Cancer Res. 1992;52:6394-6.

40. Cucinotta FA, Katz R, Wilson JW. Radial distribution of electron spectra from high-energy ions. Radiat Environ Biophys. 1998;37:259-65.

41. Goodhead DT, Thacker J, Cox R. Effects of radiations of different qualities on cells: molecular mechanisms of damage and repair (Weiss Lecture). Int J Radiat Biol. 1993;63:543-56.

42. Muroya Y, Plante I, Azzam EI, Meesungnoen J, Katsumura Y, Jay-Gerin J-P. High-LET ion radiolysis of water: visualization of the formation and evolution of ion tracks and relevance to the radiation-induced bystander effect. Radiat Res. 2006;165:485-91.

43. Plante I, Ponomarev A, Cucinotta FA. 3D visualisation of the stochastic patterns of the radial dose in nano-volumes by a Monte Carlo simulation of HZE ion track structure. Radiat Prot Dosimetry. 2011;143:156-61.

44. Mikkelsen RB, Wardman P. Biological chemistry of reactive oxygen and nitrogen and radiation-induced signal transduction mechanisms. Oncogene. 2003;22:5734-54.

45. Wu C, Parrott AM, Fu C, Liu T, Marino SM, Gladyshev VN, et al. Thioredoxin 1-mediated post-translational modifications: reduction, transnitrosylation, denitrosylation, and related proteomics methodologies. Antioxid Redox Signal. 2011;15:2565-604.

46. Formenti SC, Demaria S. Local control by radiotherapy: is that all there is? Breast Cancer Res. 2008;10:215.

47. Robbins ME, Zhao W. Chronic oxidative stress and radiation-induced late normal tissue injury: a review. Int J Radiat Biol. 2004;80:251-9.

48. Dedon PC, Tannenbaum SR. Reactive nitrogen species in the chemical biology of inflammation. Arch Biochem Biophys. 2004;423:12-22.

49. Cadet J, Douki T, Ravanat JL. Measurement of oxidatively generated base damage in cellular DNA. Mutat Res. 2011;711:3-12.

50. Deshpande A, Goodwin EH, Bailey SM, Marrone BL, Lehnert BE. Alpha-particle-induced sister chromatid exchange in normal human lung fibroblasts-evidence for an extranuclear target. Radiat Res. 1996;145:260-7.

51. Belyakov OV, Malcolmson AM, Folkard M, Prise KM, Michael BD. Direct evidence for a bystander effect of ionizing radiation in primary human fibroblasts. Br J Cancer. 2001;84:674-9.

52. Zhou H, Randers-Pehrson G, Waldren CA, Vannais D, Hall EJ, Hei TK. Induction of a bystander mutagenic effect of alpha particles in mammalian cells. Proc Natl Acad Sci USA. 2000;97:2099-104.

53. Azzam EI, de Toledo SM, Little JB. Direct evidence for the participation of gap-junction mediated intercellular communication in the transmission of damage signals from alphaparticle irradiated to non-irradiated cells. Proc Natl Acad Sci USA. 2001;98:473-8.

54. Sawant SG, Randers-Pehrson G, Geard CR, Brenner DJ, Hall EJ. The bystander effect in radiation oncogenesis: I. Transformation in $\mathrm{C} 3 \mathrm{H}$ 10T1/2 cells in vitro can be initiated in the unirradiated neighbors of irradiated cells. Radiat Res. 2001;155:397-401.

55. Ghandhi SA, Yaghoubian B, Amundson SA. Global gene expression analyses of bystander and alpha particle irradiated normal human lung fibroblasts: synchronous and differential responses. BMC Med Genomics. 2008;1:63. 
56. Bishayee A, Rao DV, Howell RW. Evidence for pronounced bystander effects caused by nonuniform distributions of radioactivity using a novel three-dimensional tissue culture model. Radiat Res. 1999;152:88-97.

57. Gerashchenko BI, Howell RW. Cell proximity is a prerequisite for the proliferative response of bystander cells co-cultured with cells irradiated with gamma-rays. Cytometry. 2003;56A:71-80.

58. Mothersill C, Seymour C. Survival of human epithelial cells irradiated with cobalt 60 as microcolonies or single cells. Int J Radiat Biol. 1997;72:597-606.

59. Xue LY, Butler NJ, Makrigiorgos GM, Adelstein SJ, Kassis AI. Bystander effect produced by radiolabeled tumor cells in vivo. Proc Natl Acad Sci USA. 2002;99:13765-70.

60. Persaud R, Zhou H, Baker SE, Hei TK, Hall EJ. Assessment of low linear energy transfer radiation-induced bystander mutagenesis in a three-dimensional culture model. Cancer Res. 2005;65:9876-82.

61. Held KD. Effects of low fluences of radiations found in space on cellular systems. Int J Radiat Biol. 2009;85:379-90.

62. Matsumoto H, Hayashi S, Hatashita M, Shioura H, Ohtsubo T, Kitai R, et al. Induction of radioresistance to accelerated carbon-ion beams in recipient cells by nitric oxide excreted from irradiated donor cells of human glioblastoma. Int J Radiat Biol. 2000;76:1649-57.

63. Azzam EI, Little JB. The radiation-induced bystander effect: evidence and significance. Hum Exp Toxicol. 2004;23:61-5.

64. Akudugu JM, Azzam EI, Howell RW. Induction of lethal bystander effects in human breast cancer cell cultures by DNA-incorporated iodine-125 depends on phenotype. Int J Radiat Biol. 2012 April 10; Epub ahead of print.

65. Mothersill C, Seymour C. Medium from irradiated human epithelial cells but not human fibroblasts reduces the clonogenic survival of unirradiated cells. Int J Radiat Biol. 1997;71:421-7.

66. Mothersill C, Seymour C. Radiation-induced bystander effects, carcinogenesis and models. Oncogene. 2003;22:7028-33.

67. Mothersill C, Seymour CB. Cell-cell contact during gamma irradiation is not required to induce a bystander effect in normal human keratinocytes: evidence for release during irradiation of a signal controlling survival into the medium. Radiat Res. 1998;149:252-62.

68. Morgan WF. Non-targeted and delayed effects of exposure to ionizing radiation: II. Radiationinduced genomic instability and bystander effects in vivo, clastogenic factors and transgenerational effects. Radiat Res. 2003;159:581-96.

69. Mothersill C, Seymour C. Radiation-induced bystander effects: past history and future directions. Radiat Res. 2001;155:759-67.

70. Hamada N, Maeda M, Otsuka K, Tomita M. Signaling pathways underpinning the manifestations of ionizing radiation-induced bystander effects. Curr Mol Pharmacol. 2011;4:79-95.

71. Blyth BJ, Sykes PJ. Radiation-induced bystander effects: what are they, and how relevant are they to human radiation exposures? Radiat Res. 2011;176:139-57.

72. Hei TK, Zhou H, Ivanov VN, Hong M, Lieberman HB, Brenner DJ, et al. Mechanism of radiation-induced bystander effects: a unifying model. J Pharm Pharmacol. 2008;60:943-50.

73. Little JB. Genomic instability and bystander effects: a historical perspective. Oncogene. 2003;22:6978-87.

74. Azzam EI, de Toledo SM, Spitz DR, Little JB. Oxidative metabolism modulates signal transduction and micronucleus formation in bystander cells from alpha-particle-irradiated normal human fibroblast cultures. Cancer Res. 2002;62:5436-42.

75. Zhou HN, Suzuki M, Randers-Pehrson R, Chen G, Trosko J, Vannais D, et al. Radiation risk at low doses may be greater than we thought. Proc Natl Acad Sci USA. 2001;98:14410-5.

76. Ghandhi SA, Sinha A, Markatou M, Amundson SA. Time-series clustering of gene expression in irradiated and bystander fibroblasts: an application of FBPA clustering. BMC Genomics. 2011;12:2.

77. Belyakov OV, Mitchell SA, Parikh D, Randers-Pehrson G, Marino SA, Amundson SA, et al. Biological effects in unirradiated human tissue induced by radiation damage up to $1 \mathrm{~mm}$ away. Proc Natl Acad Sci USA. 2005;102:14203-8. 
78. Sedelnikova OA, Nakamura A, Kovalchuk O, Koturbash I, Mitchell SA, Marino SA, et al. DNA double-strand breaks form in bystander cells after microbeam irradiation of threedimensional human tissue models. Cancer Res. 2007;67:4295-302.

79. Kovalchuk O, Zemp FJ, Filkowski J, Altamirano A, Dickey JS, Jenkins-Baker G, et al. MicroRNAome changes in bystander three-dimensional human tissue models suggest priming of apoptotic pathways. Carcinogenesis. 2010;31:1882-8.

80. Lorimore SA, Coates PJ, Scobie GE, Milne G, Wright EG. Inflammatory-type responses after exposure to ionizing radiation in vivo: a mechanism for radiation-induced bystander effects? Oncogene. 2001;20:7085-95.

81. Koturbash I, Kutanzi K, Hendrickson K, Rodriguez-Juarez R, Kogosov D, Kovalchuk O. Radiation-induced bystander effects in vivo are sex specific. Mutat Res. 2008;642:28-36.

82. Jain MR, Li M, Chen W, Liu T, De Toledo SM, Pandey BN, et al. In vivo space radiationinduced non-targeted responses: late effects on molecular signaling in mitochondria. Curr Mol Pharmacol. 2011;4:106-14.

83. Brooks AL, Retherford JC, McClellan RO. Effect of 239PuO2 particle number and size on the frequency and distribution of chromosome aberrations in the liver of the Chinese hamster. Radiat Res. 1974;59:693-709.

84. Brooks AL, Benjamin SA, Hahn FF, Brownstein DG, Griffith WC, McClellan RO. The induction of liver tumors by $239 \mathrm{Pu}$ citrate or $239 \mathrm{PuO} 2$ particles in the Chinese hamster. Radiat Res. 1983;96:135-51.

85. Mancuso M, Pasquali E, Leonardi S, Tanori M, Rebessi S, Di Majo V, et al. Oncogenic bystander radiation effects in patched heterozygous mouse cerebellum. Proc Natl Acad Sci USA. 2008;105:12445-50.

86. Blakely EA. Biological effects of cosmic radiation: deterministic and stochastic. Health Phys. 2000;79:495-506.

87. Charlton DE, Sephton R. A relationship between microdosimetric spectra and cell survival for high-LET irradiation. Int J Radiat Biol. 1991;59:447-57.

88. Cucinotta F, Nikjoo H, Goodhead DT. The effect of delta rays on the number of particle traversals per cell in laboratory and space exposures. Radiat Res. 1998;150:115-9.

89. National Research Council. Managing space radiation risk in the new era of space exploration. Washington, DC: The National Academies Press; 2008.

90. Hollowell Jr JG, Littlefield LG. Chromosome damage induced by plasma of x-rayed patients: an indirect effect of X-ray. Proc Soc Exp Biol Med. 1968;129:240-4.

91. Goh K, Sumner H. Breaks in normal human chromosomes: are they induced by a transferable substance in the plasma of persons exposed to total-body irradiation? Radiat Res. 1968;35:171-81.

92. Morgan WF, Day JP, Kaplan MI, McGhee EM, Limoli CL. Genomic instability induced by ionizing radiation. Radiat Res. 1996;146:247-58.

93. Kadhim MA, Lorimore SA, Hepburn MD, Goodhead DT, Buckle VJ, Wright EG. Alpha-particleinduced chromosomal instability in human bone marrow cells. Lancet. 1994;344:987-8.

94. Kennedy AR, Fox M, Murphy G, Little JB. Relationship between X-ray exposure and malignant transformation in C3H 10T1/2 cells. Proc Natl Acad Sci. 1980;77:7262-6.

95. Kennedy AR, Little JB. Evidence that a second event in X-ray induced oncogenic transformation in vitro occurs during cellular proliferation. Radiat Res. 1984;99:228-48.

96. Sabatier L, Dutrillaux B, Martin MB. Chromosomal instability. Nature. 1992;357:548.

97. Chang WP, Little JB. Persistently elevated frequency of spontaneous mutations in progeny of $\mathrm{CHO}$ clones surviving $\mathrm{X}$-irradiation: association with delayed reproductive death phenotype. Mutat Res. 1992;270:191-9.

98. Seymour CB, Mothersill C, Alper T. High yields of lethal mutations in somatic mammalian cells that survive ionizing radiation. Int J Radiat Biol Relat Stud Phys Chem Med. 1986;50:167-79.

99. Chang WP, Little JB. Delayed reproductive death as a dominant phenotype in cell clones surviving X-irradiation. Carcinogenesis. 1992;13:923-8. 
100. Belyakov OV, Prise KM, Trott KR, Michael BD. Delayed lethality, apoptosis and micronucleus formation in human fibroblasts irradiated with X-rays or alpha-particles. Int J Radiat Biol. 1999;75:985-93.

101. Lorimore SA, Kadhim MA, Pocock DA, Papworth D, Stevens DL, Goodhead DT, et al. Chromosomal instability in the descendants of unirradiated surviving cells after alpha-particle irradiation. Proc Natl Acad Sci USA. 1998;95:5730-3.

102. Wu LJ, Randers-Pehrson GR, Xu A, Waldren CA, Geard CR, Yu ZL, et al. Targeted cytoplasmic irradiation with alpha particles induces mutations in mammalian cells. Proc Natl Acad Sci USA. 1999;96:4959-64.

103. Prise KM, Belyakov OV, Folkard M, Micheal BD. Studies on bystander effects in human fibroblasts using a charged particle microbeam. Int J Radiat Biol. 1998;74:793-8.

104. Lehnert BE, Goodwin EH. Extracellular factor(s) following exposure to alpha particles can cause sister chromatid exchanges in normal human cells. Cancer Res. 1997;57:2164-71.

105. Zhou H, Suzuki M, Geard CR, Hei TK. Effects of irradiated medium with or without cells on bystander cell responses. Mutat Res. 2002;499:135-41.

106. Hu B, Shen B, Su Y, Geard CR, Balajee AS. Protein kinase C epsilon is involved in ionizing radiation induced bystander response in human cells. Int J Biochem Cell Biol. 2009;41:2413-21.

107. Narayanan PK, Goodwin EH, Lehnert BE. Alpha particles initiate biological production of superoxide anions and hydrogen peroxide in human cells. Cancer Res. 1997;57:3963-71.

108. Abdelrazzak AB, Stevens DL, Bauer G, O'Neill P, Hill MA. The role of radiation quality in the stimulation of intercellular induction of apoptosis in transformed cells at very low doses. Radiat Res. 2011;176:346-55.

109. Dickey JS, Baird BJ, Redon CE, Sokolov MV, Sedelnikova OA, Bonner WM. Intercellular communication of cellular stress monitored by gamma-H2AX induction. Carcinogenesis. 2009;30:1686-95.

110. Shao C, Folkard M, Prise KM. Role of TGF-beta1 and nitric oxide in the bystander response of irradiated glioma cells. Oncogene. 2008;27:434-40.

111. Narayanan PK, LaRue KEA, Goodwin EH, Lehnert BE. Alpha particles induce the production of interleukin-8 by human cells. Radiat Res. 1999;152:57-63.

112. Zhou H, Ivanov VN, Gillespie J, Geard CR, Amundson SA, Brenner DJ, et al. Mechanism of radiation-induced bystander effect: role of the cyclooxygenase-2 signaling pathway. Proc Natl Acad Sci USA. 2005;102:14641-6.

113. Ivanov VN, Zhou H, Ghandhi SA, Karasic TB, Yaghoubian B, Amundson SA, et al. Radiation-induced bystander signaling pathways in human fibroblasts: a role for interleukin-33 in the signal transmission. Cell Signal. 2010;22:1076-87.

114. Kalanxhi E, Dahle J. Genome-wide microarray analysis of human fibroblasts in response to gamma radiation and the radiation-induced bystander effect. Radiat Res. 2012;177:35-43.

115. Asur R, Balasubramaniam M, Marples B, Thomas RA, Tucker JD. Bystander effects induced by chemicals and ionizing radiation: evaluation of changes in gene expression of downstream MAPK targets. Mutagenesis. 2010;25:271-9.

116. Chaudhry MA, Omaruddin RA. Mitochondrial gene expression in directly irradiated and nonirradiated bystander cells. Cancer Biother Radiopharm. 2011;26(5):657-63.

117. Herok R, Konopacka M, Polanska J, Swierniak A, Rogolinski J, Jaksik R, et al. Bystander effects induced by medium from irradiated cells: similar transcriptome responses in irradiated and bystander K562 cells. Int J Radiat Oncol Biol Phys. 2010;77:244-52.

118. Chaudhry MA. Bystander effect: biological endpoints and microarray analysis. Mutat Res. 2006;597:98-112.

119. Iwakawa M, Hamada N, Imadome K, Funayama T, Sakashita T, Kobayashi Y, et al. Expression profiles are different in carbon ion-irradiated normal human fibroblasts and their bystander cells. Mutat Res. 2008;642:57-67.

120. Ghandhi SA, Ming L, Ivanov VN, Hei TK, Amundson SA. Regulation of early signaling and gene expression in the alpha-particle and bystander response of IMR-90 human fibroblasts. BMC Med Genomics. 2010;3:31. 
121. Iyer R, Lehnert BE. Factors underlying the cell growth-related bystander responses to alpha particles. Cancer Res. 2000;60:1290-8.

122. Shao C, Furusawa Y, Aoki M, Matsumoto H, Ando K. Nitric oxide-mediated bystander effect induced by heavy-ions in human salivary gland tumour cells. Int J Radiat Biol. 2002;78:837-44.

123. Azzam EI, de Toledo SM, Waker AJ, Little JB. High and low fluences of alpha-particles induce a G1 checkpoint in human diploid fibroblasts. Cancer Res. 2000;60:2623-31.

124. Lyng FM, Seymour CB, Mothersill C. Initiation of apoptosis in cells exposed to medium from the progeny of irradiated cells: a possible mechanism for bystander-induced genomic instability? Radiat Res. 2002;157:365-70.

125. Nagar S, Smith LE, Morgan WF. Characterization of a novel epigenetic effect of ionizing radiation: the death-inducing effect. Cancer Res. 2003;63:324-8.

126. Azzam EI, de Toledo SM, Gooding T, Little JB. Intercellular communication is involved in the bystander regulation of gene expression in human cells exposed to very low fluences of alpha particles. Radiat Res. 1998;150:497-504.

127. Shao C, Furusawa Y, Kobayashi Y, Funayama T, Wada S. Bystander effect induced by counted high-LET particles in confluent human fibroblasts: a mechanistic study. FASEB J. 2003; 17:1422-7.

128. Harada K, Nonaka T, Hamada N, Sakurai H, Hasegawa M, Funayama T, et al. Heavy-ion-induced bystander killing of human lung cancer cells: role of gap junctional intercellular communication. Cancer Sci. 2009;100:684-8.

129. Suzuki M, Tsuruoka C. Heavy charged particles produce a bystander effect via cell-cell junctions. Biol Sci Space. 2004;18:241-6.

130. Vance MM, Wiley LM. Gap junction intercellular communication mediates the competitive cell proliferation disadvantage of irradiated mouse preimplantation embryos in aggregation chimeras. Radiat Res. 1999;152:544-51.

131. Mitchell SA, Randers-Pehrson G, Brenner DJ, Hall EJ. The bystander response in C3H 10T1/2 cells: the influence of cell-to-cell contact. Radiat Res. 2004;161:397-401.

132. Autsavapromporn N, de Toledo SM, Buonanno M, Jay-Gerin JP, Harris AL, Azzam EI. Intercellular communication amplifies stressful effects in high-charge, high-energy (HZE) particle-irradiated human cells. J Radiat Res (Tokyo). 2011;52:408-14.

133. Harris AL. Emerging issues of connexin channels: biophysics fills the gap. Q Rev Biophys. 2001;34:325-472.

134. Hall EJ, Hei TK. Genomic instability and bystander effects induced by high-LET radiation. Oncogene. 2003;22:7034-42.

135. Azzam EI, de Toledo SM, Little JB. Expression of CONNEXIN43 is highly sensitive to ionizing radiation and environmental stresses. Cancer Res. 2003;63:7128-35.

136. Schubert AL, Schubert W, Spray DC, Lisanti MP. Connexin family members target to lipid raft domains and interact with caveolin-1. Biochemistry. 2002;41:5754-64.

137. Nagasawa H, Cremesti A, Kolesnick R, Fuks Z, Little JB. Involvement of membrane signaling in the bystander effect in irradiated cells. Cancer Res. 2002;62:2531-4.

138. Jensen R, Glazer PM. Cell-interdependent cisplatin killing by Ku/DNA-dependent protein kinase signaling transduced through gap junctions. Proc Natl Acad Sci USA. 2004;101:6134-9.

139. Kalvelyte A, Imbrasaite A, Bukauskiene A, Verselis VK, Bukauskas FF. Connexins and apoptotic transformation. Biochem Pharmacol. 2003;66:1661-72.

140. Tanaka M, Grossman HB. Connexin 26 gene therapy of human bladder cancer: induction of growth suppression, apoptosis, and synergy with Cisplatin. Hum Gene Ther. 2001;12:2225-36.

141. Hong X, Wang Q, Yang Y, Zheng S, Tong X, Zhang S, et al. Gap junctions propagate opposite effects in normal and tumor testicular cells in response to cisplatin. Cancer Lett. 2012;317(2):165-71.

142. Fick J, Barker II FD, Dazin P, Westphale EM, Beyer E, Israel MA. The extent of hepatocellular communication mediated by gap junctions is predictive of bystander tumor cytotoxicity in vitro. Proc Natl Acad Sci USA. 1995;92:11071-5. 
143. Freeman SM, Abboud CN, Whartenby KA, Packman CH, Koeplin DS, Moolten FL, et al. The "bystander effect": tumor regression when a fraction of the tumor mass is genetically modified. Cancer Res. 1993;53:5274-83.

144. Kuriyama S, Nakatani T, Masui K, Sakamoto T, Tominaga K, Yoshikawa M, et al. Bystander effect caused by suicide gene expression indicates the feasibility of gene therapy for hepatocellular carcinoma. Hepatology. 1995;22:1838-46.

145. Mesnil M, Piccoli C, Tiraby G, Willecke K, Yamasaki H. Bystander killing of cancer cells by herpes simplex virus thymidine kinase gene is mediated by connexins. Proc Natl Acad Sci USA. 1996;93:1831-5.

146. van Dillen IJ, Mulder NH, Vaalburg W, de Vries EF, Hospers GA. Influence of the bystander effect on HSV-tk/GCV gene therapy. A review. Curr Gene Ther. 2002;2:307-22.

147. Hamada N, Kodama S, Suzuki K, Watanabe M. Gap junctional intercellular communication and cellular response to heat stress. Carcinogenesis. 2003;24:1723-8.

148. Loewenstein WR, Rose B. The cell-cell channel in the control of growth. Semin Cell Biol. 1992;3:59-79.

149. Trosko JE, Chang CC, Madhukar BV, Klaunig JE. Chemical, oncogene and growth factor inhibition gap junctional intercellular communication: an integrative hypothesis of carcinogenesis. Pathobiology. 1990;58:265-78.

150. Yamasaki H, Mesnil M, Omori Y, Mironov N, Krutovskikh V. Intercellular communication and carcinogenesis. Mutat Res. 1995;333:181-8.

151. Mehta PP, Bertram JS, Loewenstein WR. Growth inhibition of transformed cells correlates with their junctional communication with normal cells. Cell. 1986;44:187-96.

152. Yamasaki H, Naus CC. Role of connexin genes in growth control. Carcinogenesis. 1996;17:1199-213.

153. Willecke K, Eiberger J, Degen J, Eckardt D, Romualdi A, Guldenagel M, et al. Structural and functional diversity of connexin genes in the mouse and human genome. Biol Chem. 2002;383:725-37.

154. Bedner P, Niessen H, Odermatt B, Kretz M, Willecke K, Harz H. Selective permeability of different connexin channels to the second messenger cyclic AMP. J Biol Chem. 2005;281:6673-81.

155. Goldberg GS, Moreno AP, Lampe PD. Gap junctions between cells expressing connexin 43 or 32 show inverse permselectivity to adenosine and ATP. J Biol Chem. 2002;277:36725-30.

156. Niessen H, Harz H, Bedner P, Kramer K, Willecke K. Selective permeability of different connexin channels to the second messenger inositol 1,4,5-trisphosphate. J Cell Sci. 2000;113 (Pt 8):1365-72.

157. Bevans CG, Kordel M, Rhee SK, Harris AL. Isoform composition of connexin channels determines selectivity among second messengers and uncharged molecules. J Biol Chem. 1998;273:2808-16.

158. Elsayed W, Harris AL. Selective permeability of connexin channels among inositol phosphates. Biophys J. 2004;86:583a.

159. Elsayed WA, Koreen IV, Liu YL, Harris AL. Inositol phosphates are selectively permeable through heteromeric connexin channels. Mol Biol Cell. 2004;15:183a.

160. Locke D, Stein T, Davies C, Morris J, Harris AL, Evans WH, et al. Altered permeability and modulatory character of connexin channels during mammary gland development. Exp Cell Res. 2004;298:643-60.

161. Ayad WA, Locke D, Koreen IV, Harris AL. Heteromeric, but not homomeric, connexin channels are selectively permeable to inositol phosphates. J Biol Chem. 2006;281:16727-39.

162. Cronier L, Crespin S, Strale PO, Defamie N, Mesnil M. Gap junctions and cancer: new functions for an old story. Antioxid Redox Signal. 2009;11:323-38.

163. Mesnil M, Crespin S, Avanzo JL, Zaidan-Dagli ML. Defective gap junctional intercellular communication in the carcinogenic process. Biochim Biophys Acta. 2005;1719:125-45.

164. Ammerpohl O, Trauzold A, Schniewind B, Griep U, Pilarsky C, Grutzmann R, et al. Complementary effects of HDAC inhibitor 4-PB on gap junction communication and cellular export mechanisms support restoration of chemosensitivity of PDAC cells. Br J Cancer. 2007;96:73-81.

165. Chen W, Yan C, Hou J, Pu J, Ouyang J, Wen D. ATRA enhances bystander effect of suicide gene therapy in the treatment of prostate cancer. Urol Oncol. 2008;26:397-405. 
166. Xing Y, Lu G, Xiao Y, Zeng F, Zhang Q, Xiong P, et al. [Bystander effect mediated by herpes simplex virus-thymidine kinase/ganciclovir approach on prostatic cancer cells and its regulation]. Zhonghua Yi Xue Za Zhi. 2002;82:1484-7.

167. Droge W. Free radicals in the physiological control of cell function. Physiol Rev. 2002;82:47-95.

168. Burdon RH. Control of cell proliferation by reactive oxygen species. Biochem Soc Trans. 1996;24:1028-32.

169. Finkel T, Holbrook NJ. Oxidants, oxidative stress and the biology of ageing. Nature. 2000;408:239-47.

170. Bishayee A, Hill HZ, Stein D, Rao DV, Howell RW. Free-radical initiated and gap junctionmediated bystander effect due to nonuniform distribution of incorporated radioactivity in a three-dimensional tissue culture model. Radiat Res. 2001;155:335-44.

171. Lyng FM, Seymour CB, Mothersill C. Production of a signal by irradiated cells which leads to a response in unirradiated cells characteristic of initiation of apoptosis. Br J Cancer. 2000;83:1223-30.

172. Lyng FM, Seymour CB, Mothersill C. Oxidative stress in cells exposed to low levels of ionizing radiation. Biochem Soc Trans. 2001;29:350-3.

173. Mothersill C, Stamato TD, Perez ML, Cummins R, Mooney R, Seymour C. Involvement of energy metabolism in the production of 'bystander effects' by radiation. Br J Cancer. 2000;82:1740-6.

174. Khan MA, Hill RP, Van Dyk J. Partial volume rat lung irradiation: an evaluation of early DNA damage. Int J Radiat Oncol Biol Phys. 1998;40:467-76.

175. Matsumoto H, Hayashi S, Hatashita M, Ohnishi K, Shioura H, Ohtsubo T, et al. Induction of radioresistance by a nitric oxide-mediated bystander effect. Radiat Res. 2001;155:387-96.

176. Shao C, Stewart V, Folkard M, Michael BD, Prise KM. Nitric oxide-mediated signaling in the bystander response of individually targeted glioma cells. Cancer Res. 2003;63:8437-42.

177. Huo L, Nagasawa H, Little JB. HPRT mutants induced in bystander cells by very low fluences of alpha particles result primarily from point mutations. Radiat Res. 2001;156:521-5.

178. Halliwell B. Free radicals, proteins and DNA: oxidative damage versus redox regulation. Biochem Soc Trans. 1996;24:1023-7.

179. Ames BN, Shigenaga MK, Hagen TM. Oxidants, antioxidants, and the degenerative diseases of aging. Proc Natl Acad Sci USA. 1993;90:7915-22.

180. Emerit I. Reactive oxygen species, chromosome mutation, and cancer: possible role of clastogenic factors in carcinogenesis. Free Radic Biol Med. 1994;16:99-109.

181. Cerutti P, Ghosh R, Oya Y, Amstad P. The role of the cellular antioxidant defense in oxidant carcinogenesis. Environ Health Perspect. 1994;102 Suppl 10:123-9.

182. Lampe PD, Lau AF. Regulation of gap junctions by phosphorylation of connexins. Arch Biochem Biophys. 2000;384:205-15.

183. Echetebu CO, Ali M, Izban MG, MacKay L, Garfield RE. Localization of regulatory protein binding sites in the proximal region of human myometrial connexin 43 gene. Mol Hum Reprod. 1999;5:757-66.

184. Ackerman WE, Robinson JM, Kniss DA. Despite transcriptional and functional coordination, cyclooxygenase-2 and microsomal prostaglandin E synthase-1 largely reside in distinct lipid microdomains in WISH epithelial cells. J Histochem Cytochem. 2005;53:1391-401.

185. Zhu A, Zhou H, Leloup C, Marino SA, Geard CR, Hei TK, et al. Differential impact of mouse Rad9 deletion on ionizing radiation-induced bystander effects. Radiat Res. 2005; 164:655-61.

186. Lieberman HB. Rad9, an evolutionarily conserved gene with multiple functions for preserving genomic integrity. J Cell Biochem. 2006;97:690-7.

187. Nagasawa H, Little JB. Bystander effect for chromosomal aberrations induced in wild-type and repair deficient CHO cells by low fluences of alpha particles. Mutat Res. 2002;508:121-9.

188. Weill D, Gay F, Tovey MG, Chouaib S. Induction of tumor necrosis factor alpha expression in human T lymphocytes following ionizing gamma irradiation. J Interferon Cytokine Res. 1996;16:395-402.

189. Hosoi Y, Miyachi H, Matsumoto Y, Enomoto A, Nakagawa K, Suzuki N, et al. Induction of interleukin-1 beta and interleukin- 6 mRNA by low doses of ionizing radiation in macrophages. Int J Cancer. 2001;96:270-6. 
190. Sawant SG, Randers-Pehrson G, Metting NF, Hall EJ. Adaptive response and the bystander effect induced by radiation in C3H 10T(1/2) cells in culture. Radiat Res. 2001;156:177-80.

191. Little JB, Nagasawa H, Li GC, Chen DJ. Involvement of the nonhomologous end joining DNA repair pathway in the bystander effect for chromosomal aberrations. Radiat Res. 2003;159:262-7.

192. Ward JF. The radiation-induced lesions which trigger the bystander effect. Mutat Res. 2002;499:151-4.

193. Jay-Gerin JP, Meesungnoen J, Banville P, Mankhetkorn S. Comment on "The radiationinduced lesions which trigger the bystander effect" by J.F. Ward [Mutat. Res. 499 (2002) 151-154]. Mutat Res. 2003;525:125-7.

194. Brenner DJ, Little JB, Sachs RK. The bystander effect in radiation oncogenesis: II. A quantitative model. Radiat Res. 2001;155:402-8.

195. Little MP, Wakeford R. The bystander effect in C3H 10T cells and radon-induced lung cancer. Radiat Res. 2001;156:695-9.

196. NAS. Health effects of exposure to radon (BEIR VI). Washington, DC: National Academy Press; 1998.

197. Little JB. What are the risks of low-level exposure to alpha radiation from radon? Proc Natl Acad Sci USA. 1997;94:5996-7.

198. Rees GJ, Ross CM. Abscopal regression following radiotherapy for adenocarcinoma. Br J Radiol. 1983;56:63-6.

199. Ohba K, Omagari K, Nakamura T, Ikuno N, Saeki S, Matsuo I, et al. Abscopal regression of hepatocellular carcinoma after radiotherapy for bone metastasis. Gut. 1998;43:575-7.

200. Uchida A, Mizutani Y, Nagamuta M, Ikenaga M. Effects of X-ray irradiation on natural killer (NK) cell system. I. Elevation of sensitivity of tumor cells and lytic function of NK cells. Immunopharmacol Immunotoxicol. 1989;11:507-19.

201. Camphausen K, Moses MA, Menard C, Sproull M, Beecken WD, Folkman J, et al. Radiation abscopal antitumor effect is mediated through p53. Cancer Res. 2003;63:1990-3.

202. Komarova EA, Diatchenko L, Rokhlin OW, Hill JE, Wang ZJ, Krivokrysenko VI, et al. Stress-induced secretion of growth inhibitors: a novel tumor suppressor function of p53. Oncogene. 1998;17:1089-96.

203. Mothersill C, Seymour CB. Bystander and delayed effects after fractionated radiation exposure. Radiat Res. 2002;158:626-33.

204. Mothersill C, O’Malley K, Seymour CB. Characterisation of a bystander effect induced in human tissue explant cultures by low let radiation. Radiat Prot Dosimetry. 2002;99:163-7.

205. Mesnil M, Yamasaki H. Bystander effect in herpes simplex virus-thymidine kinase/ganciclovir cancer gene therapy: role of gap-junctional intercellular communication. Cancer Res. 2000;60:3989-99.

206. Krutovskikh VA, Piccoli C, Yamasaki H. Gap junction intercellular communication propagates cell death in cancerous cells. Oncogene. 2002;21:1989-99.

207. Kennel SJ, Mirzadeh S. Vascular targeted radioimmunotherapy with ${ }^{213} \mathrm{Bi}$ - an alpha-particle emitter. Nucl Med Biol. 1998;25:241-6.

208. Huneke RB, Pippin CG, Squire RA, Brechbiel MW, Gansow OA, Strand M. Effective $\alpha$-particle-mediated radioimmunotherapy of murine leukemia. Cancer Res. 1992;52:5818-20.

209. Fisher DR. Alpha-particle emitters in medicine. In: Adelstein SJ, Kassis AI, Burt RW, editors. Dosimetry of administered radionuclides. Washington, DC: American College of Nuclear Physicians; 1990. p. 194-214.

210. Sigurdson AJ, Jones IM. Second cancers after radiotherapy: any evidence for radiationinduced genomic instability? Oncogene. 2003;22:7018-27.

211. Khan MA, Van Dyk J, Yeung IW, Hill RP. Partial volume rat lung irradiation; assessment of early DNA damage in different lung regions and effect of radical scavengers. Radiother Oncol. 2003;66:95-102. 
212. Van der Meeren A, Monti P, Vandamme M, Squiban C, Wysocki J, Griffiths N. Abdominal radiation exposure elicits inflammatory responses and abscopal effects in the lungs of mice. Radiat Res. 2005;163:144-52.

213. Leonard JM, Ye H, Wetmore C, Karnitz LM. Sonic Hedgehog signaling impairs ionizing radiationinduced checkpoint activation and induces genomic instability. J Cell Biol. 2008;183:385-91.

214. Emerit I, Quastel M, Goldsmith J, Merkin L, Levy A, Cernjavski L, et al. Clastogenic factors in the plasma of children exposed at Chernobyl. Mutat Res. 1997;373:47-54.

215. Pant GS, Kamada N. Chromosome aberrations in normal leukocytes induced by the plasma of exposed individuals. Hiroshima J Med Sci. 1977;26:149-54.

216. Diallo I, Haddy N, Adjadj E, Samand A, Quiniou E, Chavaudra J, et al. Frequency distribution of second solid cancer locations in relation to the irradiated volume among 115 patients treated for childhood cancer. Int J Radiat Oncol Biol Phys. 2009;74:876-83. 